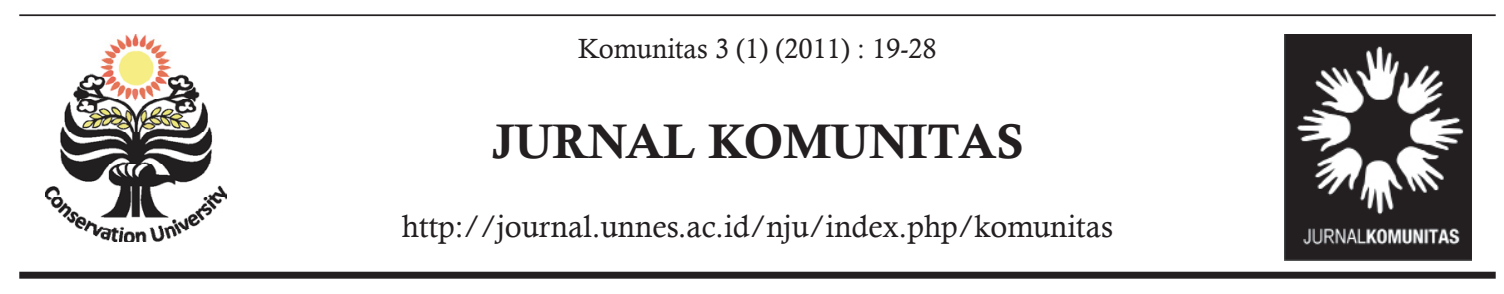

\title{
EKONOMI PEKARANGAN DI PEDESAAN JAWA
}

\section{Dede Mulyanto ${ }^{凶}$}

Jurusan Antropologi FISIP Universitas Padjadjaran, Bandung, Jawa Barat, Indonesia

\section{Info Artikel}

Sejarah Artikel:

Diterima Desember 2010

Disetujui Januari 2011

Dipublikasikan Maret 2011

Keywords:

home garden;

java;

peasant economy.

\begin{abstract}
Abstrak
Tujuan artikel ini adalah untuk menganalisa peran pekarangan sebagai sumber ketersediaan pangan, energi rumahtangga, dan uang tunai bagi rumahtangga petani. Bagi orang Jawa lahan tidak hanya tempat bekerja mereka tetapi sebagai sebuah status sosial, ekoncomi dan politik di masyarakat. Disinilah pekarangan, sebuah lahan kecil di rumah, mengambil peran ketika petani menghadapai kesulitan ekonomi yang dikarenakan lahan garapannya tidak menguntungkan. Rumusan masalahnya adalah bagaimana karakteristik desa Wetankali dan bagaimana bentuk pemanfaatan ekonomi pekarangan yang terjadi di sana. Metode penelitian yang digunakan adalah etnografis disertai survei dengan kuisioner dan analisis data sekunder. Penelitian ini dilakukan di Desa Wetankali Kecamatan Kutocilik Kabupaten Banyumas. Pekarangan bagi masyarakat Jawa merupakan benteng yang dengannya mereka dapat bertahan hidup. Pekarangan ditanami beberapa jenis tanaman ynag dapat dijual untuk menambah pendapatan rumahtangga petani. Bersaamaan dengan pertumbuhan penduduk yang naik, pekarangan berubah bentuk menjadi semakin sempit karena masyarakat lebih memilih menggunakan lahannya untuk hunian. Akibatnya, untuk rumahtangga miskin, sumber makanan pendukung dan energi murah mulai menghilang.
\end{abstract}

\begin{abstract}
The objective of this article is to analyse the role played by house yards or home garden as source of food storage, household energy, and cash for peasant household. For Javanese peasant, yard was not only a place for work, but also a space to represent economy and social status. The importance of house yards is felt in difficult situation such as economic crises and corpse failure. Research questions in this anysisis are how about the characteristics of Wetankali village and how about the pattern of using home garden or home yard there. Research method used is etnography with survey using questionaire and secondary data analysis. The research was conducted in Watankali, Kutocilik Banyumas. For Javanese, yards become a place for final defence. Peasent often plant their home garden with several kind of plants that have economical value to sell so that they will earn money from it. Along with the tendency of population growth, traditional home garden is changed to become housing complex. Consequently, for poor household, the source of food suplement and cheap energy deteriorates.
\end{abstract}

(C) 2011 Universitas Negeri Semarang

Alamat korespondensi:

ISSN 2086-5465

Kampus UNPAD, Bandung

Jawa Barat, Indonesia

E-mail: dedemulyanto@yahoo.com 


\section{PENDAHULUAN}

Tulisan ini merupakan bagian dari hasil penelitian lapangan berkenaan dengan dinamika kerja dan penghidupan rumahtangga pedesaan Jawa, khususnya desa pertanian sawah. Desa Wetankali di Kecamatan Kutocilik Kabupaten Banyumas yang diteliti berada di tepi jalan raya lintas selatan Jawa yang menghubungkan Yogyakarta dan Cilacap. Desa seluas kurang lebih 219 ha ini, dihuni paling kurang 2500 jiwa. Lebih dari $74 \%$ lahannya adalah sawah dengan rata-rata luas kepemilikan oleh penduduk desa hanya 0,2 ha. Menurut Sumastuti (2010), ekonomi pertanian orang Jawa terletak pada lingkungan sekitarnya dimana lahan tersebut menjadi sumber segala kehidupan mereka. Bagi orang Jawa di Wetankali, lahan garapan bukan sekadar sumber penghidupan tetapi juga pengaji atau sesuatu yang menjadikan pemiliknya memiliki derajat setingkat lebih tinggi dari orang lain. Selain itu lahan garapan juga sumber jaminan, baik sosial, ekonomi, maupun ontologis.

Secara tipologis, Desa Wetankali merupakan desa khas tepi jalan raya di Jawa. Rumahtangga tanpa sawah mencapai 57\% dan rumahtangga tunakisma absolut sekitar $22 \%$. Sekitar $40 \%$ penduduk dewasa adalah buruh tani. Dari sekitar 200 ha lahan pertanian, $14 \%$ milik desa yang penguasaannya diberikan kepada aparat desa dan hanya $6 \%$ saja lahan garapan milik desa yang bisa digarap bergiliran di antara penduduk. Selebihnya, yakni $80 \%$, adalah lahan milik pribadi yang satu-satunya saluran memanfaatkannya ialah melalui pasar lahan (belisewa-gadai). Karena harga beli lahan sawah mencapai 200-500 ribu rupiah per ubin (14 $\mathrm{m} 2$ ), maka mereka yang sudah berada di lapisan buruh tani sulit kemungkinannya memiliki lahan garapan. Kurang dari $1 \%$ menerjunkan diri ke dalam kerja-kerja berupah dan self-exploited di luar pertanian. Hanya sekitar $1 \%$ penduduk rumahtangga mengandalkan perdagangan, industri kecil, dan usaha kecil-kecilan sebagai sumber nafkah. Menurut Singh (dalam Elizabeth, 2007 : 31) Petani di Indonesia mayoritas merupakan petani kecil dengan penguasaan dan pengu- sahaan lahan yang relatif sempit $(<0,25 \mathrm{ha})$. Keterbatasan tersebut pada dasarnya bercirikan antara lain: (1) sangat terbatasnya penguasaan terhadap sumberdaya; (2) sangat menggantungkan hidupnya pada usahatani; (3) tingkat pendidikan yang relatif rendah; dan (4) secara ekonomi, mereka tergolong miskin. Dengan situasi semacam ini, lebih lanjut menurut Pranadji (2004) dengan lahan serba terbatas dan dengan produk andalan yang masih bernilai tambah relatif rendah sulit mengharap perekonomian pada masyarakat setempat bisa dipacu lebih tinggi lagi.

Kondisi desa tersebut membuat analisis dalam kajian ini akan terfokus pada jawaban atas pertanyaan penelitian sebagai berikut, yaitu: 1) bagaimana karakteristik desa Wetankali; dan 2) bagaimana bentuk pemanfaatan ekonomi pekarangan yang terjadi di desa Wetankali tersebut.

\section{METODE PENELITIAN}

Dalam mengkaji peran pekarangan bagi rumahtangga petani, kami menggunakan metoda etnografis yang disertai survei dengan kuisioner dan analisis data sekunder. Data sekunder terutama dikumpulkan yang terkait dengan produktivitas tanaman pekarangan. Survei dimanfaatkan untuk mempersiapkan latar sosial-ekonomi secara umum. Sedangkan data mengenai pandangan dan siasat rumahtangga petani dalam pengelolaan pekarangan digali lewat wawancara mendalam (indepth interview) dengan beberapa informan. Wawancara mendalam terhadap informan terpilih dilakukan setelah dilakukan terlebih dahulu wawancara biasa dan penelusuran data umum rumahtangga melalui survei. Informan terpilih bisa dari berbagai rentang usia, status pernikahan, atau pun tingkat pendidikan. Selain itu, pengamatan terstruktur untuk berbagai aktivitas sehari-hari penduduk, termasuk kegiatan mereka di sekitar pekarangan juga dilakukan sebagai bagian dari strategi triangulasi.

\section{HASIL DAN PEMBAHASAN}

Nasution (2008) menyatakan bahwa pada dasarnya ekonomi petani tidak jauh 
berbeda dnegan ekonomi nelayan. Mereka memiliki strategi bertahan sendiri yang memanfaatkan apa yang ada di sekitarnya. Demikian halnya pada ekonmi pekarangan, pada dasarnya semua yang ditanam di pekarangan bisa dijual. Tapi, hanya beberapa jenis tanaman yang paling banyak dijual-beli, yaitu kelapa, pisang, dan kayu-kayuan. Pekarangan merupakan bagian tak terpisahkan dari sejarah permukiman di Jawa. Menurut Gubernur Raffles (dalam Nastiti, 2003), berdirinya desa-desa di Jawa selalu bergandengan dengan pembuatan pekarangan untuk memenuhi kebutuhan sehari-hari rumah tangga petani. Menurut Penny dan Ginting (1984:5-6), pengalaman bertahun-tahun dari generasi ke generasi petani Jawa dengan pekarangan membuat mereka kurang percaya kepada pasar. Pekarangan dikelola demi menyediakan kebutuhan ekonomis untuk menjaga diri dari keganasan pasar dan melangsungkan tingkat subsistensi yang kuranglebih ajeg.

Produksi dari sekitar 3200 pohon kelapa yang produktif di Desa Wetankali bisa mencapai 164 ribu butir setahun. Paling tidak, ada dua jenis pohon kelapa yang tumbuh di pekarangan, yaitu kelapa hijau dan kelapa gading. Pohon kelapa yang sudah berusia lebih dari lima tahun bisa menjadi salah satu sumber tambahan pendapatan rumahtangga. Harga per buahnya naik-turun dari 300 sampai 1000 rupiah bergantung pada naik-turun tingkat kebutuhan produk kelapa. Pada musim-musim perhelatan seperti $\mathrm{Bu}-$ lan Besar dan Lebaran, harganya bisa tinggi. Rata-rata sepohon bisa dipanen 5-10 butir per bulan. Pada paro pertama 2007, harga sebutir buah kelapa golongan terbaik adalah 650 rupiah dan kira-kira setengahnya untuk kelapa kualitas rendah. Bila saja satu rumahtangga punya paling tidak 10-20 pohon kelapa dewasa, maka bisa diperoleh 60-100 ribu per bulan.

Tidak semua pemilik pohon kelapa menjual buah kelapanya. Ada pula yang menyewakannya kepada penyadap gula kelapa (tukang deres). Pohon yang disewakan kepada pembuat gula tidak akan menghasilkan kelapa karena penyadap justru memangkas manggar untuk mengambil nira (badek) yang sebenarnya adalah cairan yang keluar dari mayang atau tangkai bunga kelapa yang dipangkas. Setiap pohon disewa sekilo gula kelapa per bulan.

Di Wetankali sendiri tidak ada rumahtangga yang menjadi pembuat gula kelapa. Sebaliknya, sebagian penduduk di Desa Gunungsari mengandalkan penghidupan rumahtangga dengan membuat gula kelapa. Beberapa di antara mereka menyewa pohonpohon kelapa di Desa Wetankali. Hampir setiap hari (pukul 6-9 pagi) penyadap memanjat pohon kelapa yang rata-rata tingginya lebih dari duapuluh meter. Diambilnya bumbung bambu yang menampung sekitar 500 hingga $600 \mathrm{ml}$ nira dari pangkasan mayang yang ditampung kemarin sore. Setelah memasukkan bumbung baru ke pangkasan mangga yang baru, penyadap turun dan memasukkan nira ke dalam wadah. Pada sore hari, sekitar waktu sembahyang ashar, penyadap yang sama akan mengambil bumbung yang tadi pagi dipasang. Satu rumahtangga pembuat gula bisa mengelola sekitar 10 hingga 20 pohon kelapa.

Saat ini harga gula kelapa dari penyadap ke pedagang penampung berkisar 4800-5000 rupiah per kg. Dengan 17 pohon deresan, seorang penyadap bisa memperoleh 15-16 liter badek. Dari 15 liter nira ini bisa dihasilkan $2,5 \mathrm{~kg}$ gula kelapa. Jadi, sehari bisa didapat 12.000-12.500 rupiah pemasukan kotor. Bila sebulan penuh seorang penderes bekerja, maka paling tidak akan menghasilkan sekitar $75 \mathrm{~kg}$ gula kelapa. Dari jumlah tersebut, $17 \mathrm{~kg}$ gula diserahkan kepada pemilik pohon sebagai pembayaran sewa. Jumlah bersih yang bisa diperoleh penderes adalah $58 \mathrm{~kg}$ yang bisa diuangkan menjadi 278.400 rupiah per bulan atau sekitar 9000 rupiah seharinya.

Tidak jarang ada pembuat gula memiliki hubungan langganan dengan seorang pedagang penampung atau pedagang pengangkut. Bila demikian, gula-gula yang dihasilkan dijual kepada pedagang tersebut. Biasanya, pedagang penampung adalah pemilik warung bahan makanan pokok di desanya atau pedagang memang punya pangkalan penampungan. Pengikatan hubungan terjadi melalui pinjaman atau utang-utang bahan 
pangan. Penyadap biasa mengutang sejumlah tertentu bahan pangan pokok seperti beras, minyak kelapa (kletik), bumbu dapur, tahu-tempe, dan sabun.

Selain memberi penghidupan lewat nira, pohon kelapa juga menyediakan kelapa-kelapa tua yang bisa diambil daging dan sabutnya. Daging kelapa tua dikeringkan untuk dijadikan kopra dan bisa dijual kepada pedagang penampung yang ada di $\mathrm{Ku}-$ lonkali. Serabutnya dijual 50-60 rupiah ber buah kepada pedagang pengangkut yang memasok kebutuhan sabut untuk industri sapu dan keset yang ada di Kebumen.

Selain kelapa, pisang merupakan tanaman yang umumnya ada di pekarangan. Ada beberapa jenis pisang yang berbeda kegunaan dan nilai jualnya. Pisang kepok khusus untuk digoreng. Setandan pisang kepok dihargai 10-15 ribu rupiah. Pisang kepok juga diambil daunnya. Bila dijual, sepuluh lembar daun yang sudah tidak segar yang dijual ke tukang tempe seharga 600 rupiah dan 1000 per sepuluh lembar untuk daundaun besar segar yang dijual ke pasar atau warung makan. Pisang raja, yang juga banyak ditanam di bantaran kali, bila sudah berbuah biasa dihargai 7500 hingga 15.000 rupiah per tandan. Pembelinya beragam. Mulai dari penjual buah-buahan dari Pasar Kutocilik atau Pasar Sumpiuh atau pedagang pengangkut yang memasok kebutuhan industri olahan makanan dari daerah Majenang, Cilacap.

Pohon-pohon kayu boleh dikatakan semacam tabungan jangka panjang bagi rumahtangga yang menanamnya di pekarangan. Sebabnya, umur panen tanaman kayu lebih dari 5 tahun. Bahkan, mahoni (Swieteaia mahagoni L.) dan jati (Tectona grandis) baru bisa dipanen dengan kayu yang dianggap baik setelah berumur lebih dari 10 tahun. Berbeda dengan kelapa atau pisang, bibit pohon mira (Albizzia falcataria L. Fosberg), ketapang (Terminalia cattapa L.), atau mahoni harus dibeli di pasar atau langsung di tempat usaha pembibitan di Desa Kulonkali. Kayu pohon-pohon ini merupakan komoditi yang cukup berharga. Apalagi ada seorang penduduk desa yang menjadi juragan penampung kayu sekaligus pedagang kayu-kayu olahan yang pasarnya mencapai Cilacap, Kebumen, Cirebon, Bandung, dan Jakarta. Di desa tetangga pun, Kulonkali dan Kidulgunung, ada juragan-juragan kayu yang siap menerima penjualan berbagai macam kayu.

Pohon mira yang berumur lebih dari 10 tahun bisa dihargai 1-2 juta rupiah bergantung pada ukuran lingkar batang, kualitas, dan derajat kelurusannya. Semakin besar lingkar batang dan lurus, harganya semakin mahal. Pohon berumur 5 tahun atau kurang biasa dihargai 200-500 ribu rupiah; juga bergantung kualitas dan besar lingkar batangnya. Harga serupa bisa diterapkan juga untuk ketapang, angsana, dan pohon kayu lainnya yang juga sering ditanam. Kelapa yang sudah ditebang, batangnya menjadi kayu yang biasanya disebut kayu glugu. Glugu sepanjang 15-20 meter bernilai 200 ribu rupiah per batang.

Pasar kayu yang dihasilkan pekarangan cukup luas. Pedagang-pedagang pengangkut kayu pun biasa datang dari berbagai daerah mengunjungi kebun-kebun pekarangan dari satu permukiman ke permukiman lainnya menawar pohon-pohon kayu yang menurutnya berharga. Bahkan ada pedagang pengangkut kayu yang datang dari daerah Watujajar, sekitar 15 kilometer ke selatan Wetankali, yang khusus mencari kayu untuk memasok industri kapur yang memang banyak di daerah lereng perbukitan kapur itu.

Sejak pertengahan dasawarsa 1990-an, mira kian banyak ditanam di kebun-kebun pekarangan. Beberapa pemilik lahan pekarangan luas menanami lahannya khusus dengan mira. Tanaman lain seolah sekadar tanaman tumpang sari. Namun, umumnya pekarangan yang dikhususkan ditanami tanaman kayu berada jauh dari kediaman si pemilik lahan. Arti penting kayu mira sebagai sumber pendapatan menjadikan usahausaha yang terkait dengannya juga berkembang. Di desa tetangga, Kulonkali dan Kidulgunung, ada usaha pemotongan kayu di tempat yang permanen. Di Desa Gunungsari ada juga usaha layanan jasa pemotongan kayu keliling. Bila ada penduduk Wetankali yang membutuhkan jasa pemotongan kayu bisa memanggil jasa pemotongan kayu keliling ini. 
Di Kulonkali ada juga usaha tani pembibitan mira. Sejak pertengahan dasawarsa 1990-an usaha pembibitan ini dirintis seorang anak petani dari Desa Karangpetir yang pernah menjadi buruh pabrik di Bandung. Saat ini dia mengelola lahan pembibitan seluas 400 ubin $(5600 \mathrm{~m} 2)$ di lahan sawahnya yang berada di Kulonkali dibantu oleh bibinya dan sepupunya yang juga pernah menjadi buruh garmen di Ujung Berung lebih dari lima tahun. Selain bibit mira, dia juga membibitkan manggis, cengkeh, dan mahoni. Ketika pemerintah RI menggalakkan produksi dan penggunaan bahan bakar nabati dan menyarankan penanaman pohon jarak, dia juga tidak ketinggalan mengusahakan bibit-bibitnya. Tapi karena pasar bibit pohon jarak belum begitu besar, lahan yang dimanfaatkan untuk pembibitannya hanya sekitar beberapa puluh meter persegi saja.

Pasar bibit mira dan manggisnya meliputi proyek-proyek dinas kehutanan dari Sukabumi, Garut, Banyumas, Ngawi, hingga Bali. Sedangkan bibit cengkeh lebih banyak untuk memenuhi kebutuhan di Banyumas dan sekitarnya. Meski sedemikian luas jaringan pasar bibitnya, dia tidak menolak pembelian oleh penjual bibit setempat yang biasa mangkal di Pasar Kutocilik atau Pasar Sumpiuh untuk melayani pasar setempat. Bahkan pembelian perseorangan dilayaninya juga, namun bila diperkirakan pesanan partai besar tidak terganggu. Kepada pembeli skala besar dia biasa menjual 350 rupiah per bibit di musim penghujan dan 250 rupiah di musim kemarau. Kepada pedagang tingkat pertama yang menjual langsung kepada penduduk setempat di pasar dia biasa menjual 500 rupiah per batang.

Orang menyebut istilah repek untuk kegiatan mengumpulkan ranting-ranting kering, potongan kayu, atau dedaunan kering di pekarangan untuk keperluan bahan bakar dapur. Ranting dan dedaunan kering dari berbagai jenis pohon memang masih biasa diambil untuk kayu bakar. Klari (dahandaun kelapa) yang sudah mati dan kering seringnya jatuh sendiri dan diambil untuk kayu bakar. Sudah menjadi kebiasaan setempat bila klari atau kelapa jatuh sendiri boleh diambil siapa saja yang mau mengambilnya.
Pemilik pekarangan tidak biasa melarangnya. Umumnya, rumahtangga miskin yang kebetulan tinggal di sekitar pekarangan milik orang lain banyak memanfaatkan klari yang jatuh. Selain klarinya untuk kayu bakar, lidinya bisa dikumpul dan dibuat sapu.

Buah kelapa tua yang jatuh sering juga diambil. Bagi rumahtangga miskin, kelapakelapa tua yang jatuh ini dikumpul. Serabut dan batoknya dijemur hingga kering untuk kayu bakar. Daging kelapanya bisa dibuat minyak kelapa. Bila seseorang rajin mengumpulkan kelapa-kelapa tua yang jatuh, paling tidak kebutuhan akan bahan bakar dan minyak goreng rumahtangga kecilnya (sepasang suami-istri) bisa terpenuhi tanpa mengeluarkan sepeser uang. Pada Juni 2007, harga minyak goreng curah adalah 8500 rupiah per liter. Bagi rumah-rumahtangga berpenghasilan bersih sekitar 12.500 rupiah per hari, pemenuhan kebutuhan minyak goreng ini cukup memberatkan bila mengandalkan pasar minyak goreng. Jalan keluarnya bisa beragam. Selain mengurangi cara masak yang membutuhkan minyak (menggoreng) dan lebih mengutamakan cara-cara rebus atau bakar, membuat sendiri minyak dari buah kelapa tua adalah pilihan ekonomis. Dari lima buah kelapa tua bisa dihasilkan sekitar $500 \mathrm{ml}$ minyak kletik.

Pohon-pohon buah seperti dukuh, rambutan, nangka, atau mangga tidak hanya diambil buahnya. Pada suatu saat, tidak jarang pohon-pohon buah yang tua atau yang di atas tanahnya hendak didirikan bangunan akhirnya ditebang. Bila bentuk dan lingkar pohonnya dianggap bisa dimanfaatkan untuk bahan bangunan, maka kayu pohon tersebut dipotongkan ke tukang senso (usaha jasa pemotongan kayu). Kayu pohon-pohon yang dianggap kurang layak dijadikan bahan bangunan, entah karena ukuran atau bentuknya yang terlalu tidak teratur, biasanya dijadikan kayu bakar. Batang pohonnya dipotong-potong seukuran lengan menggunakan kampak atau golok (bendo). Potongan-potongan kayu ini umumnya ditumpuk di dalam atau di sekitar dapur sebagai cadangan bahan bakar setelah sebelumnya dijemur hingga dianggap kering.

Dari pengamatan sementara, jelas 
tampak bahwa tidak semua rumahtangga bergantung pada minyak tanah sebagai bahan bakar dapur. Survei atas pasokan minyak tanah di warung-warung besar di Dusun I dan Dusun II diperoleh keterangan bahwa setiap minggu, rata-rata hanya 20-25 liter minyak tanah habis dibeli. Bila di dusun satu ada sekitar 190 rumahtangga dan dianggap semuanya membeli ke satu warung, maka rata-rata penggunaan minyak tanah per rumah hanya $130 \mathrm{ml}$ atau kurang dari seperempat liter seminggu. Minyak tanah ini hanya digunakan untuk membakar kayu bakar, sampah, dan cadangan lampu minyak bila sewaktuwaktu ada pemadaman listrik. Warung pengecer (tercatat 6 buah) hanya mampu menjual 20-40 liter per minggu. Dari sini boleh dikatakan bahwa pemenuhan kebutuhan bahan bakar dapur lebih banyak dipenuhi dari pemanfaatan kayu-kayu dari pekarangan. Tidak hanya itu, kecuali beberapa penjual mi ayam, rumah makan, dan warung sate bebek di pinggir jalan raya Kutocilik, sebagian besar warung makan kecil-kecilan (beberapa di antaranya berada di Pasar Kutocilik) menggunakan kayu bakar sebagai bahan bakar pokok.

Dalam Daftar Isian Data Dasar Profil Desa Wetankali tahun 1997, tercatat 119 atau $25 \%$ dari 481 rumah menggunakan minyak tanah sebagai bahan bakar rumahtangga. Sebagian besar, yaitu 359 rumah atau $74 \%$ masih menggunakan kayu bakar sebagai bahan bakar pokok.

Selain kulit gabah dan bubuk kayu, industri pembuatan bata merah juga banyak memanfaatkan kayu-kayu bakar. Tapi, umumnya bahan-bahan ini tidak diperoleh langsung dari pekarangan. Bila kulit gabah diperoleh dari pabrik-pabrik penggilingan gabah (selipan), maka bubuk kayu dan kayu bakar didapatkan dari tempat penggergajian kayu. Kayu sisa-sisa pemotongan umumnya dijual seharga 700 ribu rupiah per rit (1 bak truk), sedangkan bubuk kayu seharga 1000 rupiah per karung (ukuran $65 \mathrm{~kg}$ ).

Industri pembuatan jenang juga menggunakan kayu-kayu bakar yang bisa dikumpul dari pekarangan. Tungku tempat memasak adonan ketan campur gula kelapa menggunakan dahan, sabut, dan batok kela- pa, dan berbagai kayu dari pekarangan.

Pohon mira atau albasia merupakan pohon kayu yang cukup dominan ditanam. Berbeda dengan pisang atau kelapa, bibit pohon mira harus dibeli. Penduduk yang hendak menanami pekarangannya dengan mira bisa membeli bibitnya di dekat Pasar Kutocilik seharga 1500-2500 rupiah per batang (yang lebih dari setengah meter). Perbedaan harga bibit berdasarkan tinggi bibit atau umur bibit. Harga sebatang pohon mira dihitung berdasarkan lingkar batang dan derajat kelurusan batangnya. Lingkar batang pohon dicapai oleh umur pohon. Umumnya, mira dipanen setelah berumur 5-10 tahun.

Untuk pembangunan sebuah rumah, pohon-pohon kayu di pekarangan bisa dimanfaatkan. Kebutuhan akan usuk rumah bisa dipenuhi dengan memanfaatkan kayu pohon glugu, mira, atau angsana. Untuk kusen, pintu, dan jendela bisa dimanfaatkan kayu pohon laban atau mahoni. Pembangunan sebuah rumah berdinding bata membutuhkan sekitar 10-15 batang mahoni (dan sejenisnya) untuk kusen dan sekitar 4-6 batang mira atau glugu untuk usuk. Untuk pembangunan rumah berdinding kayu, tentu saja kebutuhan kayu lebih banyak lagi. Ada sekitar 256 buah rumah (57\%) yang tercatat berdinding papan kayu.

Dari 445 buah rumah yang tercatat di kantor desa, sekitar 75 (17\%) berdinding bilik bambu. Rumpun-rumpun bambu hampir selalu ada di pekarangan. Mungkin hal ini terkait dengan banyaknya kegunaan bambu dalam kehidupan keseharian penduduk. Kepang atau anyaman belahan bambu bisa diperoleh dengan membelinya di Pasar Kutocilik setiap Selasa dan Jumat. Pengrajin kepang dari Desa Kretek (Gombong) biasa membawanya langsung dari desa ke Pasar Kutocilik. Bila punya waktu dan cadangan rumpun bambu, seseorang juga bisa membuatnya sendiri dari bahan-bahan yang tersedia.

Satu rumpun bambu, rata-rata ditumbuhi 30-40 batang bambu. Untuk membuat satu bilik anyaman bambu ukuran $3 \times 4$ meter, dibutuhkan sekitar sepuluh batang bambu. Sementara jenis bambu yang dibutuhkan adalah bambu tali (pring tali). Dalam pem- 
bangunan rumah berdinging tembok, bambu lebih dimanfaatkan dalam proses kerja dan bukan bagian dari bangunan rumah itu sendiri, yaitu sebagai pancang penyangga kegiatan penembokan dan pelaburan. Tetapi, sebagian rumah dari rumah-rumahtangga miskin justru menggunakan bambu jenis ini sebagai usuk penyangga genting.

Bagi rumahtangga pembuat gula kelapa, bambu tali dimanfaatkan dalam wujudnya sebagai bumbung penampung nira. Beberapa perkakas dapur rumahtangga miskin, seperti centong dan gayung, juga dibuat dengan memanfaatkan gabungan bambu dan batok kelapa. Besek tempat makanan-makanan ringan juga dibuat dari bambu tali ini. Pembuat tempe memanfaatkan tali dari bambu untuk mengikat bungkusan tempenya.

Tidak semua rumahtangga yang memelihara pekarangan menjual hasil yang bisa didapat darinya. Selain pohon-pohon yang menghasilkan kayu, tidak jarang pekarangan, terutama yang berada tepat di belakang atau di samping rumah, ditanami pohon buah-buahan seperti pepaya, jeruk, sirsak atau jambu. Buah-buah populer seperti pisang dan pepaya menyediakan tambahan asupan gizi, selain juga sebagai perantara penting pemeliharaan hubungan ketetanggaan dan kekerabatan. Buah-buah pisang atau pepaya (Carica papaya L.) tidak jarang menjadi buah tangan untuk sanak-saudara yang berkunjung atau ketika berkunjung ke sanak-saudara di desa tetangga. Pepaya juga menghasilkan daun yang tidak jarang diolah sebagai lalapan dan jamu penggugah nafsu makan.

Selain itu ada juga sayur-mayur seperti bayem (Amarantus caudatus Rumph.), lombok, dan katu (Sauropus androgynus L.). Lombok-lombok diambil untuk memenuhi kebutuhan dapur meski sesekali seorang pedagang sayur atau pemilik warung bahan makanan menawarkan untuk membelinya. Bayem yang ditanam lebih dari 30 batang bisa dijual kepada pedagang sayur-mayur 500 rupiah per unting (bungkus daun jati berisi sejumlah 25-30 batang/sekitar 800 gram) meski biasanya dimakan saja sebagai sayur.

Kluwih atau sukun (Artocarpus communis Forst) juga tidak biasa dijual tapi dimakan sendiri buahnya. Buah-buah ini menjadi makanan pelengkap atau pengganti singkong yang berguna sebagai suguhan makanan ringan untuk tamu. Hal sama berlaku untuk umbi-umbian. Selain singkong, jenis umbi yang dimakan antara lain ganyong, gumbili, dan talas. Bagi rumahtangga yang memelihara ternak kecil seperti kambing atau domba, daun-daun berbagai jenis umbi juga sering dijadikan pakan ternak; terutama untuk mengurangi kebutuhan menyediakan rumput yang hanya tersedia di pinggiran sungai dan lapangan desa. Ritual Yasinan (pembacaan Surat Yaasiin bagi yang telah meninggal dunia) dan ritual-ritual lain seperti slametan atau tahlilan selalu menyajikan makanan ringan di akhir acara. Makanan yang umumnya disediakan tuan rumah antara lain rebusan ubi jalar, goreng singkong, atau keripik selain juga buah-buahan. Ubi atau singkong biasanya diambil dari pekarangan atau pematang yang ditanami sehari sebelumnya. Kebiasaan ini mengurangi pengeluaran dana-dana sosial. hiouveauvbn

Beberapa tanaman akar-akaran seperti lengkuas, jahe, dan kunyit juga jarang sekali dijual dan lebih sering dimanfaatkan langsung. Pohon pisang tidak hanya menghasilkan buah dan daun yang berguna. Batang pisang tidak jarang dimanfaatkan untuk beberapa keperluan. Dalam ritual kematian setempat, batang pisang digunakan sebagai alas jenazah. Beberapa batang pohon pisang dijajar untuk mengalasi jenazah yang akan dimandikan. Dalam proses pemandian ini, air diupayakan agar seketika melarutkan najis yang mungkin masih melekat. Untuk itu diperlukan alas yang tidak menggenangkan air pemandian.

Meski sejak pertengahan dasawarsa 1990-an berbagai jenis sesaji, baik di rumah kediaman maupun di sawah sudah tidak lagi populer (sebagian orang mengaitkannya dengan masuknya organisasi keagamaan Muhammadiyah), namun beberapa bentuk upacara tradisional Jawa masih dijalankan. Beberapa jenis tanaman di pekarangan malah sepertinya khusus ditanam untuk memenuhi kebutuhan bahan-bahan ritual tertentu. Kelapa gading tidak banyak ditanam. Buahnya bukan terutama untuk dijual atau dijadikan 
minyak. Dalam upacara memperingati tujuhbulan usia kandungan (pitung wulanan/ mitoni), kelapa gading merupakan bagian penting. Sebelum dibelah dua, buahnya digambar dua wajah tokoh pewayangan Jawa, yaitu Arjuna dan Srikandi. Konon agar tampilan fisik dan perilaku si anak yang dilahirkan kelak meniru tampilan fisik dan perilaku tokoh wayang tersebut. Bila kelak yang lahir laki-laki diharapkan wajahnya setampan dan perilakunya sesopan Arjuna, dan bila kelak yang lahir perempuan diharapkan wajahnya secantik dan sebaik Srikandi. Dari tururan beberapa informan, secara umum ritual ini tidak lagi marak dilakukan, kecuali untuk beberapa keluarga kalangan atas.

Dalam upacara ruwatan (penyucian) yang masih dijalankan beberapa keluarga, penampilan seni wayang kulit masih menjadi unsur terpenting. Malah, upacara ruwat ini hanya bisa dijalankan melalui pergelaran wayang kulit semalam suntuk. Upacara penyucian ini ditujukan kepada anak keturunan yang berkedudukan khusus dalam keluarga seperti anak tunggal (baik laki-laki maupun perempuan), lima bersaudara lakilaki, anak perempuan ketiga dari lima saudara, satu-satunya anak perempuan (atau lakilaki), dan sebagainya. Sebelum pernikahan dilaksanakan terhadap anak-anak dengan kedudukan khusus ini, wajib dilaksanakan ruwatan untuk menghindari bencana atau kecelakaan fatal dalam hidup karena perilaku Betara Kala. Dalam pergelaran wayang kulit, dua batang pohon pisang (gedebog) diperlukan sebagai pijakan wayang-wayang. Dalam sesajinya, buah pisang yang disajikan tidak boleh sembarangan. Hanya jenis pisang raja tertentu, yaitu raja-sajen. Karena itu pisang raja sajen banyak juga ditanam di pekarangan (selain karena harganya lebih mahal daripada pisang raja-bandung).

Selain pisang dan kelapa, beberapa bahan penting dalam sesaji dan ritual ziarah makam juga diperoleh dari pekarangan, yaitu berbagai jenis bunga-bungaan. Ada enam jenis bunga yang biasa digunakan sebagai bagian dari rangkaian upacara (kembang setaman), yaitu mawar merah (Rosa damascena Mill.), mawar putih (Rosa alba), kenanga (Canagium odoratum Baill.), melati (Jasmi- num sambac L.), cempaka (Michelia alba DC.), dan srigading (Nyctanthes arbor-trestis L.). Dari amatan selama 5 hari, dari keenam jenis bunga tersebut, empat di antaranya sering ditemukan di beberapa petak pekarangan, yaitu mawar merah, mawar putih, kenanga, dan melati.

Di Wetankali pekarangan berfungsi sebagai sumber penghasilan, bahan bakar (rumah tangga dan industri), bahan bangunan, bahan pangan, dan bahan upacara. Bagi rumah tangga petani penggarap dan petani yang masih memiliki lahan, pekarangan juga merupakan salah satu sumber jaminan hari tua. Pengolahan dan kerja-kerja di sawah membutuhkan banyak curahan tenaga kerja. Ketika memasuki masa tua dan tubuh tidak lagi mampu mengerahkan tenaga kerja yang besar, maka pengolahan lahan pekarangan bisa menutupi banyak kebutuhan rumah tangga. Tanaman-tanaman kayu dan buahbuahan berumur panjang bisa menjadi cadangan pemenuhan kebutuhan rumah tangga petani-petani lanjut usia. Berbagai macam sayur dan bumbu dapur bisa diperoleh tanpa banyak mengeluarkan uang dan tenaga untuk membudidayakannya.

Pengaktifan kembali pemanfaatan hasil pekarangan sepenuhnya demi pemenuhan kebutuhan rumah tangga seringkali dikaitkan dengan guncangan-guncangan yang menimbulkan krisis secara luas (Hohnholz: 1986). Sebagai contoh yang paling banyak diinformasikan adalah ketika Krisis 19971998 terjadi (dan kekeringan yang mendahuluinya sejak 1996). Pengakuan pedagang pengangkut kelapa yang membeli langsung kelapa-kelapa dari penduduk menjelaskan bahwa sejak akhir 1998, pemilik pohon kelapa tidak lagi merelakan sabut sebagai bagian dari harga jual buah kelapanya. Para pedagang pengangkut harus mengupas buah kelapa di tempat, menyerahkan sabutnya kepada pemilik pohon, dan hanya membawa buah kelapa yang sudah dikupas tersebut. Sebelum 1998, pedagang pengangkut boleh saja membawa serta sabutnya yang bisa dijual kembali kepada pengrajin sapu dan keset atau, terutama, untuk cadangan pasokan kayu bakar rumah tangganya. Kebiasaan ini hilang karena pemilik pohon juga mengum- 
pulkan sabut sebagai cadangan bahan bakar rumah tangga.

Bagi rumah tangga miskin, pekarangan dengan segala tanaman kayunya merupakan gudang bahan bakar gratis. Di Wetankali ada kebiasaan yang dipahami semua orang bahwa apa saja yang jatuh tanpa disengaja di atas tanah pekarangan boleh diambil siapa saja yang berkenan. Ranting pohon, dahan kelapa, dan buah kelapa tua boleh diambil. Selain itu, bila pemilik pekarangan menjual atau menebang salah satu atau beberapa pohon kayunya, maka sudah lumrah bila tetangga-tetangganya yang lebih miskin boleh saja memungut potongan kecil, reranting, dan daun-daun pohon yang ditebang. Kebiasaan ini menjadi semacam pelindung bagi rumah-rumah tangga miskin yang tidak mampu membeli bahan bakar. Di musim paceklik, ketika sedikit sekali kemungkinan memperoleh kerja-kerja tani, buruh tani berkeliaran berburu ranting dan potongan kayu demi memenuhi kebutuhan bahan bakar.

Selain sebagai sumber cadangan bahan bakar rumah tangga, hasil-hasil pekarangan, terutama singkong juga sumber pangan pokok di masa krisis pangan. Memang, secara agronomis dengan sekali setahun saja sebuah rumah tangga petani menanam singkong di lahan beberapa belas $\mathrm{m} 2$, bahaya kelaparan sebagai akibat kegagalan panen padi tercegah paling tidak selama 3 sampai 4 siklus tanam (Hohnholz 1986: 185). Bagi rumah tangga buruh tani miskin, selain sebagai salah satu sumber uang tunai, menanam singkong di sekitar rumah bisa mengurangi kebutuhan beras sepanjang musim. Menurut Van der Eng (1996: 99-100, hingga 1970-an singkong berperan penting ketika permintaan akan pangan meningkat dan belum bisa dipenuhi oleh produksi padi yang ada. Sebelum tahun 1940-1970, singkong yang banyak ditanam di sawah, tegalan, dan pekarangan merupakan salah satu tanaman komoditi. Namun, sejak 1970-an ada kecenderungan menjadi bahan pangan cadangan, dan di beberapa tempat di Jawa menjadi bahan pangan sehari-hari (Nibbering 1991: 115). Terutama bagi rumah tangga miskin, umbiumbian merupakan cadangan pangan murah yang bisa tumbuh tanpa banyak perlakuan.
Beberapa pisang diambil buahnya selagi belum begitu matang. Pisang-pisang ini dimanfaatkan sebagai makanan rebus yang cukup bisa mengurangi kebutuhan akan beras atau sekadar penambah ramai ragam makanan sehari-hari.

Di sisi lain, kebutuhan akan perkembangan pertanian sebagai cara untuk meningkatkan kesejahteraan petani juga harus menjadi bagian integratif yang tidak terpisahkan dalam proses pembangunan. Suseno (2007) menyatakan bahwa salah satu kunci untuk meningkatkan kesejahteraan petani adalah pemerintah harus memperhatikan sektor pertanian lebih serius, terintegratif dan memiliki keberpihakan kepada nasib petani. Keberpihakan terhadap nasib petani, akan mendorong berkembangnya sektor pertanian dalam skala luas. Dengan keberpihakan ini, semua kebijakan yang akan diambil harus terfokus pada upaya meningkatkan kesejahteraan petani. Sikap keberpihakan ini harus meniadi landasan bagi kebijakan pemerintah ke depin. Sesudah terintegrasi, diharapkan semua sektor ikut bergerak sehingga pertanian, perkebunan, peternakan dan perikanan bisa dijadikan landasan bagi pembangunan ekonomi berkelanjutan. Langkah ini telah dipraktekkan China,-Thailand, dan Taiwan dan ternyata mereka berhasil.

\section{SIMPULAN}

Dengan kesimpulan yang sama dapat dikatakan bahwa pekarangan juga merupakan semacam benteng menghadapi ketidakpastian perubahan alam. Seperti halnya pasar yang seringkali menutup saluran perolehan kebutuhan pokok bagi sebagian rumah tangga, begitu pula bencana-bencana alam yang tidak jarang memperkecil peroleh bahan pangan atau cadangannya. Pengalaman ini tentunya tidak hanya menumbuhkan semacam cara pandang terhadap hidup dan kehidupan seperti yang terwakili oleh konsep nasib, tapi juga seperangkat siasat untuk menghadapinya. Gangguan-gangguan subsistensi, apalagi yang mencapai derajat krisis pangan karena bencana alam-seperti yang diingat penduduk di akhir dasawarsa 1950an-membuat petani di Wetankali tidak be- 
gitu saja mempercayakan keterjaminan pangannya dari sawah sepenuhnya.

Persoalannya, pertumbuhan rumah mengakibatkan menyusutnya luasan pekarangan secara umum. Hingga sekarang perluasan cakupan tanah-tanah yang dijadikan rumah memang belum mencapai tahap ketika sawah-sawah beralih fungsi. Tapi, alihalih mengubah sawah, pertumbuhan rumah tangga baru akan cenderung mengubah pekarangan. Artinya, luasan bidang yang menjadi benteng ketahanan pangan dan bahan bakar bagi rumah tangga miskin ini menyempit. Di masa depan yang tak begitu jauh, penyempitan ini akan semakin menjadi-jadi karena mereka yang bermigrasi ke luar desa dan tidak begitu berhasil akan kembali ke desa pada suatu titik perjalanan hidupnya. Para pensiunan pegawai negeri yang hidup berkecukupan di kota-kota tidak jarang pula yang kembali ke desa dan mendirikan rumah di sana. Sebagai desa yang berada di tepi jalan raya yang pertumbuhan jasa layanan publiknya cukup berkembang, maka migrasi masuk pegawai-pegawai negeri yang ditugaskan ke sekitar desa juga akan mendesak alih fungsi lahan pekarangan menjadi kediaman.

\section{DAFTAR PUSTAKA}

Elizabeth, R. 2007. Fenomena Sosiologis Metamorphosis Petani: Ke Arah Keberpihakan Pada Masyarakat Petani Di Pedesaan Yang Terpinggirkan Terkait Konsep Ekonomi Kerakyatan.
Forum Penelitian Agro Ekonomi. Volume 25 No. 1, hal. $29-42$

Hohnholz, J.H. 1986. Ubi Kayu sebagai Bahan Makanan dan Peranannya dalam Perekonomian di Asia Tenggara, dalam J.H. Hohnholz (ed.) Geografi Pedesaan: Masalah Pengembangan Pangan. Jakarta: Yayasan Obor Indonesia, hlm. 173-192

Murid, Y. 2010. Ekonomi Laki-laki, Ekonomi Perempuan. Jurnal Komunitas, 2 (2): 59-67

Nastiti, T.S. 2003. Pasar di Jawa Masa Mataram Kuna Abad VIII-XI Masehi. Jakarta: Pustaka Jaya

Nasution, Z. 2008. Perkembangan Ekonomi Masyarakat Nelayan Perairan Umum "Lebak Lebung". Sodality: Jurnal Transdisiplin Sosiologi, Komunikasi dan Ekologi Manusia, 2 (2): 249-264

Nibbering, J.W. 1991. Crisis and Resilience in Upland Use in Java, dalam Joan Hardjono (ed.) Indonesia: Resources, Ecology, and Environment. Singapore: Oxford University Press

Penny, D.H. \& Meneth G. 1984. Pekarangan, Petani dan Kemiskinan: Suatu Studi tentang Sifat dan Hakekat Masyarakat Tani di Sriharjdo Pedesaan Jawa. Yogyakarta: UGM Press dan Yayasan Agro Ekonomika

Pranadji, T. dan Hastuti, E.L. 2004. Transformasi Sosio-Budaya Dalam Pembangunan Pedesaan. Jurnal AKP, 2 (1): 77-92

Sumastuti, E. 2010. Potensi Sektor Pertanian di Jawa Tengah. Jurnal Ilmu-Ilmu Pertanian. 6(1): 5468

Suseno, D dan Suyatna, H. 2007. Mewujudkan Kebijakan Pertanian Yang Pro-Petani. Jurnal Ilmu Sosial Dan Ilmu Politik, 10 (3): 267-294

Van der Eng, P. 1996. Chalenging Changes: Current Themes in the Economic History of Indonesia, dalam HEHA-Bulletin, Tijdschrift voor de economische geschiedenis in Nederland 10 (2): 89-113 